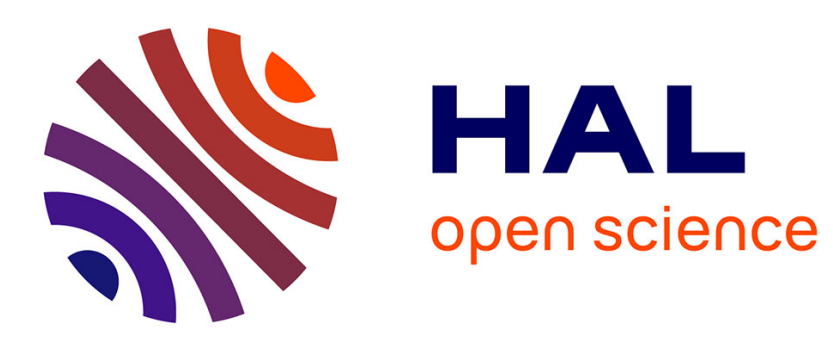

\title{
A comparative study of two media for the enumeration of lactobacilli in cheese
}

\author{
R. Poffé, H. Vanheusden
}

\section{To cite this version:}

R. Poffé, H. Vanheusden. A comparative study of two media for the enumeration of lactobacilli in cheese. Le Lait, 1986, 66 (3), pp.317-322. hal-00929072

\section{HAL Id: hal-00929072}

\section{https://hal.science/hal-00929072}

Submitted on 1 Jan 1986

HAL is a multi-disciplinary open access archive for the deposit and dissemination of scientific research documents, whether they are published or not. The documents may come from teaching and research institutions in France or abroad, or from public or private research centers.
L'archive ouverte pluridisciplinaire HAL, est destinée au dépôt et à la diffusion de documents scientifiques de niveau recherche, publiés ou non, émanant des établissements d'enseignement et de recherche français ou étrangers, des laboratoires publics ou privés. 


\title{
NOTE TECHNIQUE
}

\section{A comparative study of two media for the enumeration of lactobacilli in cheese}

\author{
R. POFFE and H. VANHEUSDEN \\ Laboratory of Industrial Microbiology and Biochemistry \\ Catholic University of Leuven, Belgium
}

\begin{abstract}
Résumé
Etude comparative de deux milieux pour le dénombrement des lactobacilles dans le fromage
\end{abstract}

Pour la détection et le dénombrement des lactobacilles dans diverses variétés de fromages belges pendant la maturation, deux milieux de dénombrement, le milieu MRS et le milieu au gluconate (GLUC) - un milieu sélectif pour le dénombrement des lactobacilles appartenant aux groupes Betabacterium et Streptobacterium - furent comparés. En semi-anaérobiose la croissance était meilleure sur MRS, alors que le GLUC donnait des colonies minuscules. En moyenne on dénombrait significativement $(\mathrm{P}<0,01)$ plus de lactobacilles sur MRS que sur GLUC. En anaérobiose stricte la croissance fut stimulée, de sorte que l'on dénombrait plus de colonies $(\mathrm{P}<0,05)$ qu'en semi-anaérobiose, mais globalement le comptage sur MRS restait supérieur au comptage sur GLUC. De chaque milieu, 120 colonies, isolées de fromages différents, furent identifiées. Sur MRS et GLUC les mêmes espèces du genre Lactobacillus furent identifiées : L. plantarum, L. buchneri, L. casei var. casei et L. brevis. En moyenne plus de bactéries hétérofermentaires furent détectées sur GLUC que sur MRS, mais cette différence n'était pas statistiquement significative. Par conséquent, pour le dénombrement des Bêtabactéries et Streptobactéries, aucune différence en sélectivité entre le GLUC et le MRS n'a pu être constatée.

Mots clés : Fromage - Lactobacilles - Enumération - Milieux - MRS agar - Milieu au Gluconate - L. plantarum - L. casei - L . buchneri - L. brevis.

Key words: Cheese - Lactobacilli - Enumeration - Media - MRS agar - Gluconate agar - L. plantarum - L. casei - L. buchneri - L. brevis.

\section{Introduction}

Lactobacilli are quantitatively a very important group of bacteria during the ripening of cheese, reaching often numbers of $10^{7} / \mathrm{g}$ and more. They were generally considered to be without importance in cheese ripening. Some investigators, however, proved that many strains of lactobacilli can cause off-flavours in cheese. 
SHARPE and FrANKLIN (1962) found that lactobacilli isolated from cheese were able to produce $\mathrm{H}_{2} \mathrm{~S}$ from sulphur containing amino acids. BADINGs et al. (1968) showed that $L$. plantarum and $L$. casei can cause a phenolic taste in Gouda cheese and more recently STADHOUDERs et al. (1983) confirmed their previous observations on the negative effect of some lactobacilli on the quality of cheese, producing off-flavours and gas formation during ripening.

Mesophilic lactobacilli, especially Streptobacteria and Betabacteria, are found to be responsible for defects in taste and texture (TE WHAITI and FrYER, 1982). From this point of view it would be very useful to dispose of a counting medium, on which only the two above cited groups of lactobacilli can grow. TE WHAITI and FRYER (1982) developed a new medium, Gluconate agar (GLUC) for the enumeration of lactobacilli in cheese. On this medium only Streptobacteria and Betabacteria may grow, while Thermobacteria, Leuconostoc species and streptococci are inhibited.

In this study lactobacilli were enumerated in various belgian cheeses, comparing the GLUC medium with the generally used MRS agar, recommended by the Sub-Committee of the International Committee on Nomenclature of Bacteria (HANSEN, 1968). On MRS however, Thermobacteria, Leuconostoc species and Pediococci may grow occasionally. Colony counts and colony diameters on both media were compared. Colonies were isolated, purified and examined for identification.

\section{Materials and methods}

\section{A. Cheeses and cheese sampling}

Five different varieties of belgian cheeses were examined, 4 semisoft cheeses (Véritable Loo, Grande Ferme, Père Joseph and Maredsous) and 1 soft cheese (Wijnendale, prepared from bactofuged raw milk). Only minimum 6 weeks old cheeses were considered. Samples $(25 \mathrm{~g})$ were taken at the centre of the cheese and homogenized. From the well mixed sample $1 \mathrm{~g}$ was taken aseptically and suspended in $9 \mathrm{ml}$ of $2 \%$ sodium citrate warmed up at $45^{\circ} \mathrm{C}$. After complete blending, decimal dilutions up to $10^{-6}$ were made in sterile quarter strength Ringer solution.

\section{B. Media}

The used media for the enumeration of lactobacilli were MRS agar (Oxoid, CM 361) and Gluconate agar (TE WhAITI and FRYER, 1982). GLUC was composed as follows (in g/litre medium) : trypticase 10.0 ; beef extract 3.0 ; yeast nitrogen base $5.0 ; \mathrm{KH}_{2} \mathrm{PO}_{4} 2.0$; sodium gluconate 40.0 ; sodium acetate 2.5 ; $\mathrm{MgSO}_{4} 0.2 ; \mathrm{MnSO}_{4} 0.05$; tween $801.0 \mathrm{ml}$; agar 15.0. The $\mathrm{pH}$ was adjusted at 5.3 with acetic acid and the medium was steam sterilized $\left(100^{\circ} \mathrm{C}\right)$ for $20 \mathrm{~min}$.

Plates were counted after 5 days of incubation at $30^{\circ} \mathrm{C}$. Semi-anaerobic incubation was obtained by covering the poured plates, after solidification of the agar, with a top layer of a non inoculated agar medium of the same composition. Anaerobic incubation was carried out in a special jar, using the Anaerocult A system of Merck (Darmstadt, W. Germany). 


\section{Identification of colonies}

From the plates containing between 30 and 300 colonies, 20 colonies chosen at random were picked up and transferred in tubes MRS or GLUC agar by stab inoculation. After purification the isolates were examined by Gram reaction and catalase. When it was established that they were Gram + rod shaped cells and catalase negative, they were further examined for identification by physiological and biochemical tests according to SHARpe et al. (1966) and Bergey's Manual for Determinative Bacteriology (1974). Following tests were performed : growth at $15^{\circ} \mathrm{C}$ and $45^{\circ} \mathrm{C}$; production of gas from glucose and gluconate; production of ammonia from arginine; hydrolysis of esculine and the fermentation of amygdaline, arabinose, cellobiose, galactose, mannitol, maltose, melezitose, melibiose, raftinose, salicin, sorbitol, rhamnose, sucrose, trehalose and xylose. All the tests, except the growth at $15^{\circ} \mathrm{C}$ and $45^{\circ} \mathrm{C}$, were carried out in small test tubes $(120 \times 12 \mathrm{~mm})$, according to the miniaturized method described by JAYNE-WilLIAMS (1976).

\section{Results}

Lactobacilli were counted in 10 different cheeses: 3 cheeses of the type "Véritable Loo", 3 of the type "Grande Ferme", 2 of the type "Wijnendale" and 1 of both types "Père Joseph" and "Maredsous". All the counts were carried out in duplicate. It was soon obvious that the growth on MRS was more luxuriant than on GLUC : after semi-anaerobic incubation, colonies on MRS were well developed (colony diameter of $1.5-3 \mathrm{~mm}$ ) while on GLUC they were small $(0.5-1 \mathrm{~mm})$. Also differences in colony counts were observed between the two media (table 1): on the average the number of colonies on MRS was $7.663 \pm$ 0.852 ( $\log _{10}$ colony count; $95 \%$ confidence limits) and $7.518 \pm 0.950$ on GLUC. When variations between the different cheese types were not taken into account the colony counts on MRS were significantly higher by the paired t-test $(\mathrm{t}=3.060 ;$ d.f. $=19 ; \mathrm{P}<0.01)$. Anaerobic incubation stimulated the growth on both media so that not only the colony diameter increased $(2-4 \mathrm{~mm}$ on MRS and 1-2 $\mathrm{mm}$ on GLUC) but also the colony counts. Both on MRS and GLUC significantly more colonies were counted under anaerobic incubation $(\mathrm{t}=5.375$; d.f. $=11 ; \mathrm{P}<0.01)$. As for semi-anaerobic incubation, the colony counts on MRS were also higher than those on GLUC $(\mathrm{t}=3.537$; d.f. $=5 ; \mathrm{P}<0.05)$.

As both media normally do not support the growth of the same lactobacilli species-on GLUC especially Streptobacteria and Betabacteria develop, whereas on MRS, besides all Lactobacilli species also bacteria from the genera Leuconostoc and Pediococcus may grow-colonies developed (semi-anaerobically) on both media were examined for identification. In all 120 colonies were isolated from MRS and 120 from GLUC. Following Lactobacillus species were found: L. plantarum, L. buchneri, L. casei var. casei and L. brevis. Their distribution on MRS and GLUC is given in table 2. The results show that about the same proportion of the different Lactobacillus species was found on both media. However, more heterofermentatives ( $L$. buchneri $+L$. brevis) were isolated from GLUC $(20 \%)$ than from MRS $(15 \%)$, but this difference was not significant $(\mathrm{t}=1.745$; d.f. $=6 ; \mathrm{P}<0.200)$. 
TABLE I

Enumeration of lactobacilli on MRS and GLUC after 5 days of incubation at $30^{\circ} \mathrm{C}$ under semi-anaerobic and anaerobic conditions

Dénombrement des lactobacilles sur MRS et GLUC après 5 jours d'incubation à $30^{\circ} \mathrm{C}$ en semi-anaérobiose et anaérobiose stricte

\begin{tabular}{|c|c|c|c|c|c|}
\hline \multirow{3}{*}{ Cheese } & \multirow{3}{*}{$\begin{array}{l}\text { Number } \\
\text { of sample }\end{array}$} & \multicolumn{4}{|c|}{ Number of colonies $\left(\times 10^{6} / \mathrm{g}\right.$ cheese $)$} \\
\hline & & \multicolumn{2}{|c|}{$\begin{array}{l}\text { Semi-anaerobic } \\
\text { incubation }\end{array}$} & \multicolumn{2}{|c|}{$\begin{array}{l}\text { Anaerobic } \\
\text { incubation }\end{array}$} \\
\hline & & MRS & GLUC & MRS & GLUC \\
\hline Père Joseph & 1 & $\begin{array}{l}28.5 \\
31\end{array}$ & $\begin{array}{l}15.3 \\
15.6\end{array}$ & $\begin{array}{l}39 \\
37\end{array}$ & $\begin{array}{l}30 \\
27\end{array}$ \\
\hline Maredsous & 1 & $\begin{array}{l}31 \\
34\end{array}$ & $\begin{array}{l}10 \\
11.6\end{array}$ & $\begin{array}{l}48 \\
45\end{array}$ & $\begin{array}{l}16.5 \\
17\end{array}$ \\
\hline Grande Ferme & $\begin{array}{l}1 \\
2 \\
3\end{array}$ & $\begin{array}{l}43 \\
39 \\
10.2 \\
11.8 \\
6.8 \\
9.8\end{array}$ & $\begin{array}{l}36 \\
32 \\
11.4 \\
13.2 \\
6.3 \\
5.6\end{array}$ & $\begin{array}{l}41 \\
55\end{array}$ & $\begin{array}{l}37 \\
41\end{array}$ \\
\hline Wijnendale & $\begin{array}{l}1 \\
2\end{array}$ & $\begin{array}{r}90 \\
94 \\
114 \\
119\end{array}$ & $\begin{array}{l}38 \\
34 \\
60 \\
60\end{array}$ & & \\
\hline \multirow[t]{2}{*}{ Véritable Loo } & $\begin{array}{l}1 \\
2 \\
3\end{array}$ & $\begin{array}{r}164 \\
172 \\
262 \\
46 \\
61 \\
63\end{array}$ & $\begin{array}{r}175 \\
189 \\
287 \\
43 \\
87 \\
91\end{array}$ & & \\
\hline & & \multicolumn{4}{|c|}{$\begin{array}{c}\text { Nombre de colonies }\left(\times 10^{6} / g \text { de fromage) }\right. \\
\text { Semi-anaérobiose Anaérobiose }\end{array}$} \\
\hline
\end{tabular}

\section{Discussion}

Many selective media for the enumeration of lactobacilli are described in the litterature (VAN KEER et al., 1983). Most of them are not $100 \%$ selective and other bacteria as streptococci, pediococci, Leuconostoc species may grow occasionally. A medium, such as GLUC, allowing only the growth of mesophilic lactobacilli (Streptobacteria and Betabacteria) would therefore be very useful for the examination of cheese. These investigations, however, have proved that GLUC 
TABLE II

Distribution of the different Lactobacillus species on MRS and GLUC in some cheese varieties

Distribution des différentes espèces de Lactobacillus sur MRS et GLUC dans quelques variétés de fromage

\begin{tabular}{|c|c|c|c|c|c|c|c|c|c|c|c|c|}
\hline \multirow{3}{*}{ Cheese } & \multicolumn{12}{|c|}{ Number of isolates } \\
\hline & \multicolumn{6}{|c|}{ MRS } & \multicolumn{6}{|c|}{ GLUC } \\
\hline & 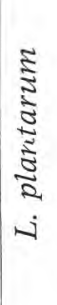 & $\begin{array}{l}\tilde{J} \\
\tilde{J} \\
\tilde{J} \\
\tilde{J} \\
\tilde{z} \\
\tilde{J} \\
\tilde{J} \\
\dot{J} \\
-1\end{array}$ & 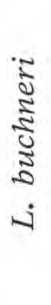 & $\begin{array}{r}-1 \\
5 \\
5 \\
5 \\
5 \\
5\end{array}$ & 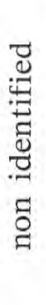 & Total & 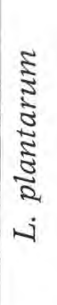 & $\begin{array}{l}\tilde{J} \\
\tilde{\Xi} \\
\tilde{J} \\
\tilde{\Xi} \\
\tilde{J} \\
\tilde{J} \\
\tilde{J} \\
\tilde{J} \\
\dot{-}\end{array}$ & 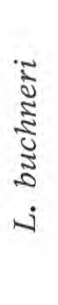 & $\frac{4}{9}$ & 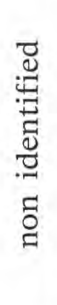 & Total \\
\hline Véritable Loo & 25 & -a & 13 & - & 2 & 40 & 24 & - & 14 & - & 2 & 40 \\
\hline Grande Ferme & 54 & - & - & - & 6 & 60 & 52 & - & 6 & - & 2 & 60 \\
\hline Wijnendale & 11 & 3 & 1 & 4 & 1 & 20 & 8 & 6 & 1 & 3 & 2 & 20 \\
\hline Total & 90 & 3 & 14 & 4 & 9 & 120 & 84 & 6 & 21 & 3 & 6 & 120 \\
\hline \multicolumn{13}{|c|}{$\begin{array}{l}\text { Nombre de colonies isolées } \\
\text { a not detected } \\
\text { a non détecté }\end{array}$} \\
\hline
\end{tabular}

in every respect was inferior to MRS, the used reference medium : colonies were smaller and also the colony counts were, both under semi-anaerobic and anaerobic incubation, lower than those on MRS. When variations between the different cheese types were not taken into account-only differences between the two media and not between the cheeses are here considered-the observed differences were statistical significant. The fact that more colonies were counted on MRS than on GLUC cannot be attributed to the growth on MRS of other groups of bacteria than on GLUC, since from both media only Betabacteria and Streptobacteria were isolated. The identified Lactobacillus species agree with those isolated by other investigators from other sorts of cheese (REITER and SHARPE, 1971 ; Stadhouders et al., 1983). Consequently, it could not be established if GLUC was more selective for Betabacteria and Streptobacteria than MRS. Besides, the poor growth on GLUC makes this medium less efficient for the isolation of lactobacilli from cheese.

Reçu le 18-6-1985. 


\section{References}

Badings H.T., Stadhouders J., Van Duin H., 1968. Phenolic flavor in cheese. J. Dairy Sci., $51,31-35$

Bergey's Manual of Determinative Bacteriology, 1974. Eds. William and Wilkins, NewYork, U.S.A.

Hansen P.A., 1968. A report by the Taxonomic Subcommittee on Lactobacilli and closely related organisms. American Type Culture Collection, Rockville, Md., U.S.A.

JAYNE-WILLIAMS D.J., 1976. The application of miniaturized methods for the characterization of various organisms isolated from the animal gut. J. Appl. Bacteriol., 40, 189-200.

REITER B., Sharpe M.E., 1971. Relationship of the microflora to the flavour of Cheddar cheese. J. Appl. Bacteriol., 34, 63-80.

Sharpe M.E., FrankLIN J.G., 1962. Production of hydrogen sulphide by lactobacilli with special reference to strains isolated from Cheddar cheese. VIIIth Int. Congr. Microbiol., Canada, B. II, 3, 46-48.

Sharpe M.E., Fryer T.F., Smith D.G., 1966. Identification of the lactic acid bacteria. In : Identification methods for microbiologists. Part A, eds. Gibbs B.M. and Skinner F.A., Academic Press, London and New York, 65-81.

Stadhouders J., Kleter G., Lammers W.L., Tuinte J.H.M., 1983. Growth of lactobacilli in Gouda cheese. Voedingsmiddelen Technol., 16, 26, $20-23$.

Te Whaiti I.E., Fryer T.F., 1982. The isolation of lactobacilli from cheese using gluconate agar. XXI Int. Dairy Congr. Moscow, U.S.S.R., I, 376.

Van Keer C., Van Melkebere L., Vertriest W., Hoozee G., Schoonberghe E., 1983. Growth of Lactobacillus species on different media. J. Inst. Brew., 89, 361-363. 